\title{
Production of electricity employing sewerage lines using a micro cross flow turbine
}

\author{
Muhammad Hamza Tahir ${ }^{1 *}$, Shoukat Ali Mugheri ${ }^{2}$, Salman Ahmad ${ }^{3}$, Mughees Shahid ${ }^{4}$, Nouman \\ Zaffar $^{5}$, Muhammad Arsalan Malik ${ }^{6}$, Muhammad Asad Saeed ${ }^{7}$ \\ 1,2,3,4,5,6,7 Department of Mechanical Engineering, Pakistan Institute of Engineering and Technology (PIET) Multan, PAKISTAN \\ *Corresponding Author's e-mail: djhhh11@gmail.com, Tel +92-332-7445569

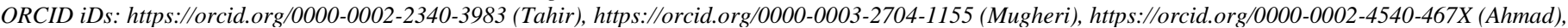 \\ https://orcid.org/0000-0001-6849-2855 (Shahid), https://orcid.org/0000-0002-1439-048X (Zaffar), https://orcid.org/0000-0001-9412-604X (Malik), \\ https://orcid.org/0000-0002-5044-2873 (Saeed)
}

\begin{abstract}
In the design of cross flow turbines, efficiency is a significant parameter. The crossflow turbine for developing nations is the most cost-efficient electricity generation source and often used in isolated power systems. This research work analyzes the potential of electricity production using a micro-cross flow turbine from sewage lines. To measure the hydraulic potential of the sewage's wastewater, flow rate at the connection point was investigated by experimentation on site and the efficiency of the micro cross flow turbine was evaluated. The experimental results show that the hydraulic potential of the selected point for electricity production is enough throughout the year. It also shows that the micro-cross flow turbine can be used effectively to produce electricity from the sewage at the link points. The highest efficient $2 \mathrm{~mm}$ head was observed with a maximum flow rate of $0.112 \mathrm{~m}^{3} / \mathrm{s}$. Depending on the flow rate, the turbine velocity was $103-263 \mathrm{rpm}$. The maximum power of shaft was $284.58 \mathrm{~W}$ and the highest power generated was $196.24 \mathrm{~W}$. The maximum overall efficiency was $68.2 \%$. This article discusses the design, efficiency, operation and cost of low-head micro crossflow turbines.
\end{abstract}

Keywords: Electricity Generation, Hydraulic Potential, Micro Cross Flow Turbine, Sewage

DOI: http://dx.doi.org/10.4314/ijest.v12i2.8

\section{Introduction}

In today's global renewable energy, the role of hydro plants is becoming critically important. The cost-effective way of supplying electricity to streetlights can be the small scale renewable energy sources, which helps to reduce the domestic grids load (Nakase et al., 2014; Chen and Choi, 2013). The immense dependence on conventional energy sources had severe environmental impacts and power outages, which have raised the worldwide consciousness for renewable resources (Acharya et al., 2015). Hydropower is a major and sustainable renewable energy source among several other renewable sources which can be utilized due to its appealing economics and the accessibility of fundamental technology. Among the hydropower systems the CFMT is the most preferable. A turbine essentially turns hydraulic power by rotating shaft into mechanical power (Adhikari and Wood, 2018). The power transmission is carried out through blades (Alexander et al., 2009). Currently, because of its easy design and manufacturing, the crossflow micro turbines in low head and low water flow rates are used. A standard Cross-Flow Turbine comprises of two major parts, the nozzle and the runner moreover cross flow turbine performance is strongly influenced by turbine structure configuration and flow characteristic on turbine blades, nozzle geometry, blade inclination and number of turbine blades (Aplicada, 2004). The angle of the runner serves as a absorber to capture the kinetic energy of the water that strikes the surface of the blade causing the runner to convert that energy of the water into mechanical energy (Aree, 2013).

Sewage consists of rainwater and water which human beings and manufacturing operations release to the sewer (Cabra, 2014). The wastewater consists of human waste from homes, workstations and industrial sector is included in the sewer system. The 
annual waste-water generation in the Islamic Republic of Pakistan is estimated at 6,414 billion $\mathrm{m}^{3}$ (BCM), consisting of 4,953 BCM of municipalities annually and of 0,395 BCM of industrial products annually (Chichkhede et al., 2016), also waste water of 0.886 billion cubic meter per year is being directly used for irrigation purpose in farming sector. The irrigation land served by waste water is 33610 hectors (Dakers and Martin, 1982). The article aims to use sewage as a source of energy. Waste water sludge utilization is negligible in Pakistan, the number of sewage treatment facilities Multan region is 11, and there is none smallhydraulic power plant to utilize this sewage potential (Date and Akbarzadeh, 2009). Water treatment systems include drainage systems like sewage pipes, treatment equipment like treatment plants and additional installations such as pump stations.

The complete length of waste water pipes of Multan region in Fiscal Year 2011 was about $9.79 * 106 \mathrm{~km}$ (Desai, 1993). Hydraulic energy potential is therefore assumed to be scattered throughout the country in sewage pipes (Diego and Restrepo, 2012). As a result, the use of drainage waste for electricity production which could contribute to the local electrical power production as local consumption is immense (Diez, 2008). But this generation of sewage energy has never taken place and the hydraulic energy potential has not been studied in the drainage plants in Pakistan (Elbatran et al., 2015; Falconi et al., 2009; Ghalichechian et al., 2008; Ikeda et al., 2010; Jeon et al., 2005). Thus the desire to achieve hydraulic micro-scale electricity production with an energy output of less than $90 \mathrm{~kW}$ is growing (Alexander et al., 2009; Singh and Nestmann, 2011; Stark et al., 2011; Yasuyuki et al., 2014; Runner, 2015; Uchiyama et al., 2016).

Such area units for micro-hydraulic turbines often contained foreign material such as dropped leaves, twigs, human and animal waste. The foreign matter can be removed from a filter installed at the start of the micro-hydraulic turbine. However, the operational costs of such machinery increased due to additional components. We are committed to developing a MCFT that is outstanding in terms of foreign matter passage without stirring the effectiveness of cross flow turbine (San and Nyi, 2018; Uchiyama et al., 2018). The runner has a cavity around the main axis to allow waste matter passage. Wastewater includes both home-based hair and vegetable waste, kitchens and human waste. It is important that turbine is not blocked by waste matter to effectively produce energy from sewage (Sinagra et al., 2014). Therefore, the micro cross flow turbine, we are developing pledges to be efficient for sewage electricity production.

Several research studies were conducted to develop the optimum setup of the crossflow turbine, both by experimental and numerical methods. Most of the research contains information regarding impact on the shape of the nozzle, the ratio of diameter of the runner, the inlet arch and the number of turbine blades. Sinagraa et al. (2014) outlined a straightforward and thorough procedure for the design and discharge of a crossflow turbine. In this document a basic but stringent method was described to design a crossflow turbine with a discharge control unit. The authors noted reduced turbine effectiveness, minimized surface inlet and simulated fluid dynamics. The theoretical framework of the synchronous design of turbine parameters was developed by Vincenzo et al. (2012) and the new computing capabilities were fully exploited. Table 1 sums up the significant prior research (Murtaza, 2010; Nasir, 2015; Asia, 2009; Patel, 2016; Paul, 1997; Pareira. 2009; Prajapati, 2015; Ranterarung, 2018; Reihani, 2014; Ricardo, 2007; Desai, 2015).

Table 1. Previous Research Work

\begin{tabular}{lcccccc}
\hline \multirow{2}{*}{ Source } & $\boldsymbol{d}$ & ${ }^{\boldsymbol{b}} \mathbf{1 b}$ & $\mathbf{R}_{\mathbf{2}} / \mathbf{R}_{\mathbf{1}}$ & $\mathbf{N}_{\mathbf{b}}$ & $\boldsymbol{q}_{\mathbf{s}}$ & $\boldsymbol{h}$ \\
\cline { 2 - 7 } & $\mathbf{( d e g )}$ & $\mathbf{( d e g})$ & $\mathbf{( - )}$ & $(-)$ & $(\mathbf{d e g})$ & $(\boldsymbol{\%})$ \\
\hline Macmore and Merryfield (1949) & 16 & 30 & 0.66 & 20 & - & 68 \\
Varga (1959) & 16 & 39 & 0.66 & 30 & - & 77 \\
Durali (1979) & 16 & 30 & 0.68 & 24 & - & 76 \\
Dakers and Martin (1982) & 22 & 30 & 0.67 & 20 & 69 & 69 \\
Johnson et al. (1982) & 16 & 39 & 0.68 & 18 & 60 & 80 \\
Nakase et al. (2014) & 15 & 39 & 0.68 & 26 & 90 & 82 \\
Durgin and Fay (1984) & 16 & 39 & 0.68 & 20 & 63 & 66 \\
Khosrowpanah et al. (1988) & 16 & 39 & 0.68 & 15 & 58 & 80 \\
Hothersall (1985) & 16 & - & 0.66 & 21 & - & 75 \\
Ott and Chappell (1989) & 16 & - & 0.68 & 20 & - & 79 \\
Fiuzat and Akerkar (1989) & 20 & 39 & 0.68 & 20 & 90 & 89 \\
Desai (2017) & 32 & 39 & 0.60 & 30 & 90 & 88 \\
Totapally and Aziz (1994) & 24 & 39 & 0.68 & 35 & 90 & 90 \\
\hline
\end{tabular}

The aim of this research is to investigate the possible generation of hydraulic power from sewage drain to achieve micro-scale electricity production with an energy output of less than $90 \mathrm{~kW}$ to overcome greenhouse gasses emission, smog formation during winter season and other environmental damages caused by conventional coal fired, LNG and oil powered power plants in Punjab province. First, a clear hydraulic energy potential for the disposal is focused on the sewage at the connecting point. Secondly, this research examines the hollow micro cross flow turbine's effectiveness and passage of foreign matter. 


\section{Flow duration and hydraulic potential}

\subsection{Local Wastewater System Outline}

Several small sewage lines are connected to a waste disposal plant in Southern Punjab, Multan, Pakistan through LMQ road Sewage Line. The total sewage region amounts to approx. 46 square kilometers, the population is around 3,300,000, and the treatment capability is 7,04 x $10^{5} \mathrm{~m}^{3} /$ day (as of April 1, 2015) (Khan and Badshah, 2014). The LMQ Sewerage line covers WASAmanaged government sewage systems. The linked portion is called the point of attachment. In fig. 1, circular symbols illustrate the LMQ Sewerage line attachment points. The sewage pipe has an opening at the attachment points and the flow rate is measured all over the year. This research examines the flow rate at one of the attachment points to find feasible sewage hydraulic power generation.

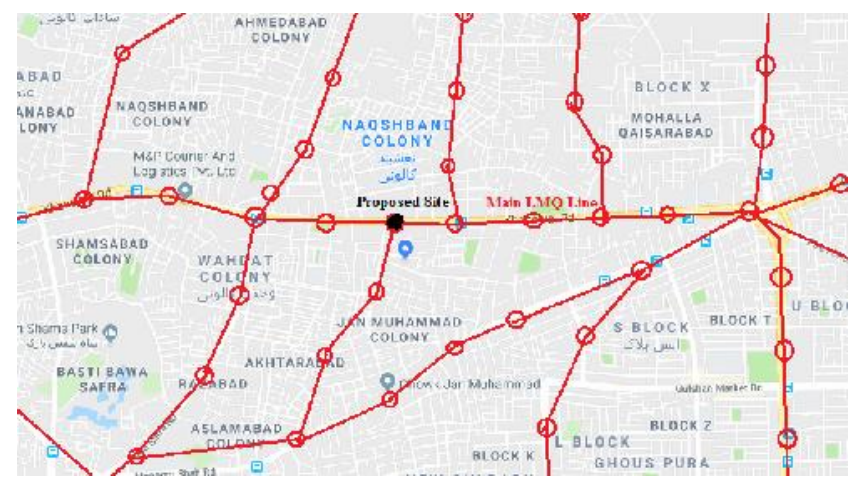

Figure 1. LMQ Sewerage Line and Proposed Site

\subsection{Attachment Points Flow Duration}

The daily average flow is pre-measured at the installation site to precisely calculate the energy output when a hydraulic power plant is constructed. A flow duration curve was created by arranging the daily average flow rate data provided by WASA in a descending order. Fig. 2 illustrates the flow duration curves for the planned site at the attachment points. The 97th, 187th, 277th, and 357th highest flow rates are known as the high flow, regular flow, low flow and droughty flow. In Fig. 2, Q1, Q2, Q3 and Q4 are respectively referred to these flow rates, and they are listed in Table 2. The ratio between high-and low-water discharge (Q1$\mathrm{Q} 3$ ) and the normal water discharge $\mathrm{Q} 2(\mathrm{Q} 1-\mathrm{Q} 3) / \mathrm{Q} 2$, at points of attachment, is 0.138 , illustrating that the variation in the annual flow rate is low. Fig. 3 illustrate the attachment point's flow rate in which the mean, minimum, and maximum flow rates are specified for each month. The average and minimum values are almost the same and equal to the Q2.

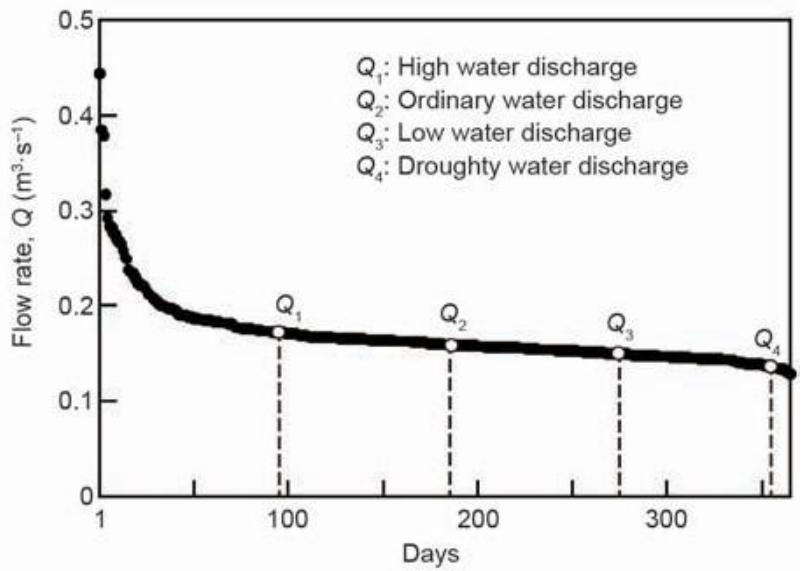

Figure 2. Flow duration at the attachment points 
Table 2. Sewage flow rates

\begin{tabular}{ll}
\hline \multicolumn{1}{c}{ Flow Rate } & LMQ Sewerage Line $\left(\mathbf{m}^{3} \cdot \mathbf{s}^{-\mathbf{1}}\right)$ \\
\hline High $Q_{1}$ & 0.172 \\
Ordinary $Q_{2}$ & 0.159 \\
Low $Q_{3}$ & 0.150 \\
Droughty $Q_{4}$ & 0.112 \\
\hline
\end{tabular}
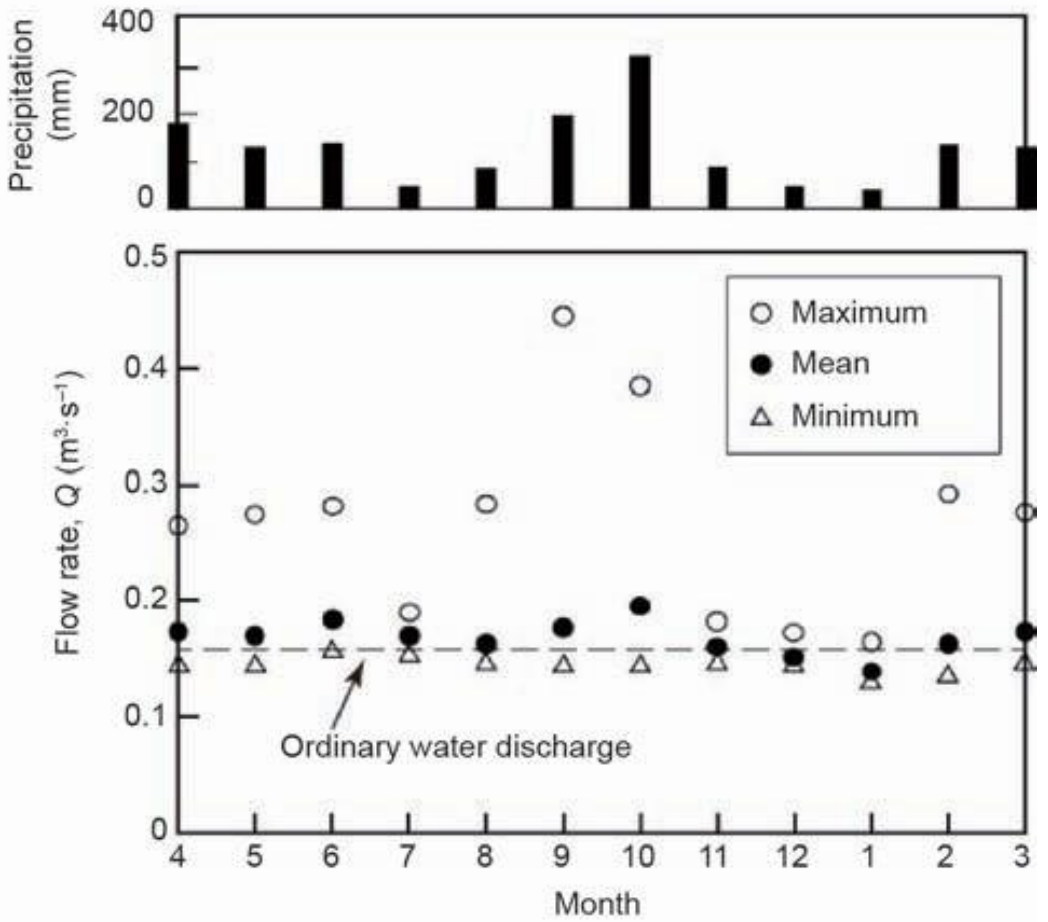

Figure 3. Monthly flow rate

\subsection{Hydraulic Potential at Attachment Point}

The potential of the fluid, i.e. P, flowing is expressed as:

$$
P=\frac{1}{2} \rho Q u^{2}
$$

where, $\rho$ is the fluid density and $Q$ is the flow rate.

The velocity can be calculated from flow rate $\mathrm{Q}$ if the sewage is supposed to occupy $11 \%$ of the pipe's area and velocity is calculated at the ordinary $0.159 \mathrm{~m}^{3} \mathrm{~s}^{-1}$ discharge, the hydraulic potential is estimated at $328 \mathrm{~W}$.

\section{Design of Micro Cross Flow Turbine}

The two main components of a typical CFT are the nozzle and the runner. The primary role of the system is that the overall head present is converted in kinetic energy and the water is conveyed to the blades (Sammartano et al., 2013). 


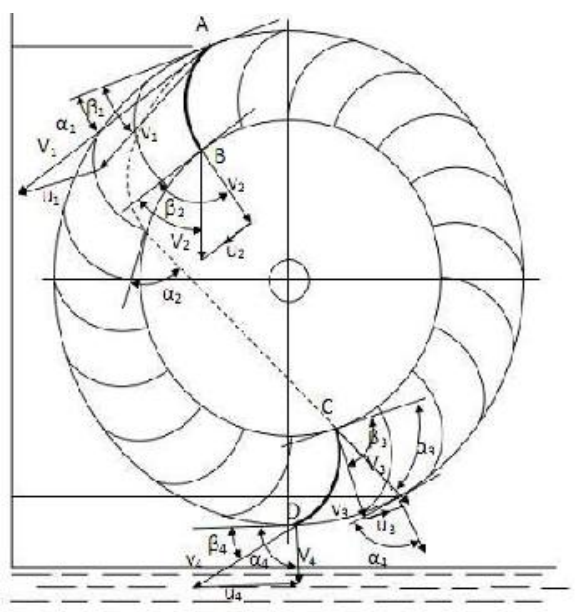

Figure 4. Path of water through turbine

As shown in Fig 4, the water enters from point A and strikes a blade AB. The water then flows across the runner's interior. The water strikes a blade CD again and passes through the exit (San and Nyi, 2018).

\subsection{Shaft Design}

A shaft transmits hydraulic power to mechanical power, the shaft is a rotating element of the system, generally circular in cross sections, with components like transmission gear, pulleys, flywheels, cranks, pulleys and other power supply components installed. It subjects to torque when transmitting energy at a certain rotational speed (Khan and Badshah, 2014).

\subsection{Design Procedure of Cross Flow Turbine}

The calculations for design involve the following steps.

Table 3. Design parameters for $290 \mathrm{~W}$ cross flow turbine

\begin{tabular}{ll}
\hline \multicolumn{1}{c}{ Parameter } & Value \\
\hline Generator Power $(\mathrm{P})$ & $196.24 \mathrm{~W}$ \\
Head $(\mathrm{H})$ & $2 \mathrm{~mm}$ \\
Flow Rate (Q) & $0.112 \mathrm{~m}^{3} / \mathrm{s}$ \\
Overall Efficiency $\left({ }_{0}\right)$ & $68.2 \%$ \\
\hline
\end{tabular}

\subsection{Shaft Power}

The shaft power of the turbine is calculated as

$$
P=\eta \rho g Q H
$$

\subsection{Turbine Efficiency}

The efficiency can be calculated as (Sinagra et al., 2014)

$$
\eta=\frac{1}{2} K_{c}^{2}(1+\Psi) \cos (\alpha)^{2}
$$

where, $\psi=$ an empirical coefficient (about 0.98)

$\mathrm{K}_{\mathrm{c}}=$ coefficient of water velocity,

(0.98 0.95)

3.5 Specific Speed

$$
N_{s}=\frac{172.556}{H^{0.425}}
$$

3.6 Turbine Speed

$$
\mathrm{N}=\frac{\mathrm{N}_{\mathrm{g}} \times \mathrm{H}^{1.25}}{\sqrt{\mathrm{P}}}
$$




\subsection{Runner Outer Diameter}

Depending on the flow conditions, the runner diameter is selected. When the turbine has a higher flow, a larger turbine diameter is selected, and a lower turbine diameter is selected for the low water flow circumstances. It can be calculated as (Singh, 2012)

$$
D_{1}=\frac{K_{u} 60 K_{c} 2 g \sqrt{H}}{\pi N}
$$

\subsection{Length of Runner}

Runner length is calculated as:

$$
L=\frac{Q}{K D_{1} K_{c} 2 g \sqrt{H}}
$$

\subsection{Radial Rim Width}

The radial rim width (m) can be calculated as (Stark et al., 2011):

$$
a=0.17 D_{1}
$$

\subsection{Radius of Blade Curvature}

The turbine works very efficiently with the curvature of the blade. The size of the turbine varies directly with it. It is calculated as (T., 1976):

$$
r_{c}=0.16 D_{1}
$$

\subsection{Circle pitch of blade shape arc}

The radius of circle pitch of blade shape arc is calculated as (Tiwari and Shrestha, 2017):

$$
R_{0}=0.3 D_{1}
$$

\subsection{Blade Spacing}

The spacing of the blade enables the water for maximum production, the distance between the blades depends on the number of blades used in the runner. It is calculated as: (Uchiyama and Morita, 2017)

$$
t=\frac{K D_{1}}{\sin \beta_{1}}
$$

\subsection{Number of Blades}

The selection of the number of blades for turbine runners is very essential, fewer blades can cause the turbine to be used insufficiently and an excess number of blades can lead to pulse energy and a decrease in turbine effectiveness. It is calculated as: (Umer, 2014)

$$
n=\frac{\pi D_{1}}{t}
$$

\subsection{Shaft Diameter}

It should have a value to bear the load on the turbine. It is calculated as:

$$
d_{s}=150 \sqrt[3]{\frac{P}{N}}
$$

Using above mentioned equations, the design parameters of cross flow turbine are calculated and shown in Table 4 .

Table 4. Calculated parameters turbine runner

\begin{tabular}{lccc}
\hline \multicolumn{1}{c}{ Parameters } & Symbol & Results & Unit \\
\hline Blade angle & $\beta_{1}$ & $39^{\circ}$ & - \\
Runner outer diameter & $\mathrm{D}_{1}$ & 0.4 & $\mathrm{M}$ \\
Runner length & $\mathrm{L}$ & 0.97 & $\mathrm{M}$ \\
Outer circle radius & $\mathrm{r}_{1}$ & 0.152 & $\mathrm{M}$ \\
Inner circle radius & $\mathrm{r}_{2}$ & 0.105 & $\mathrm{M}$ \\
Radius of pitch circle & $\mathrm{R}_{0}$ & 0.3 & $\mathrm{M}$ \\
blade curvature radius & $\mathrm{r}_{\mathrm{c}}$ & 0.125 & $\mathrm{M}$ \\
Radial rim width & $\mathrm{a}$ & 0.137 & $\mathrm{M}$ \\
Number of blades & $\mathrm{n}$ & 20 & - \\
\hline
\end{tabular}




\section{CAD Models}

Several micro-turbines have been designed in the past, but presented restrictions in fabrication processes and design geometries (Mtalo et al., 2010). Researchers at MIT developed a planar model in order to be more compatible with existing fabrication capabilities and to ensure viability in order to compensate low head conditions in the sewerage line (Williamson et al., 2014). The rotor was designed using the model reported by Yang et al. (2009) and Nishi et al. (2014) but changes were made in the runner. The runner has a cavity to allow passage of waste matter and foreign material through the blades without blocking wastewater flow and eliminating the need for filtration mechanism and minimizing the cost of system.

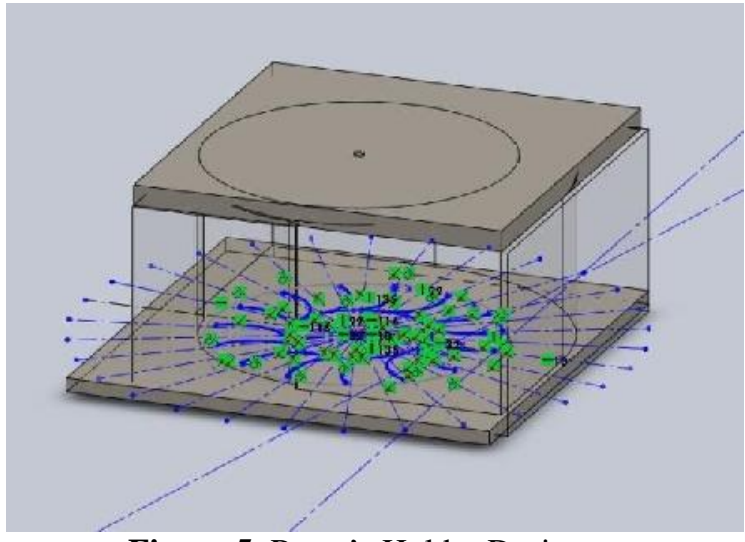

Figure 5. Rotor's Holder Design

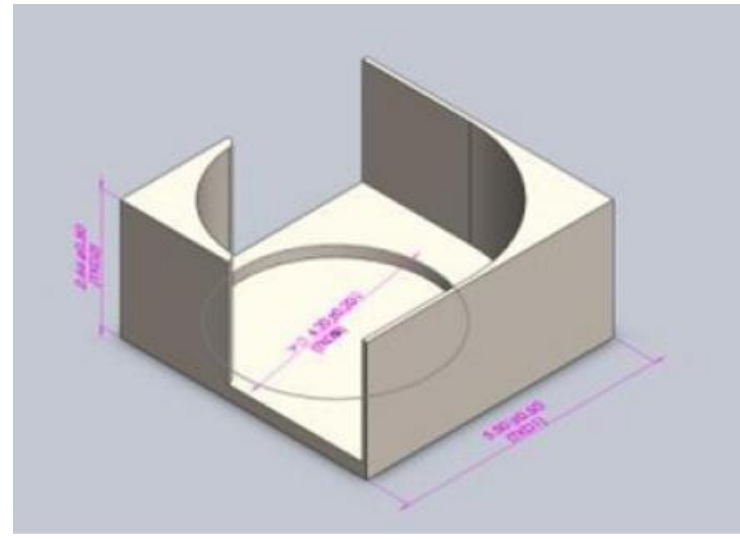

Figure 6. Holder Isometric View

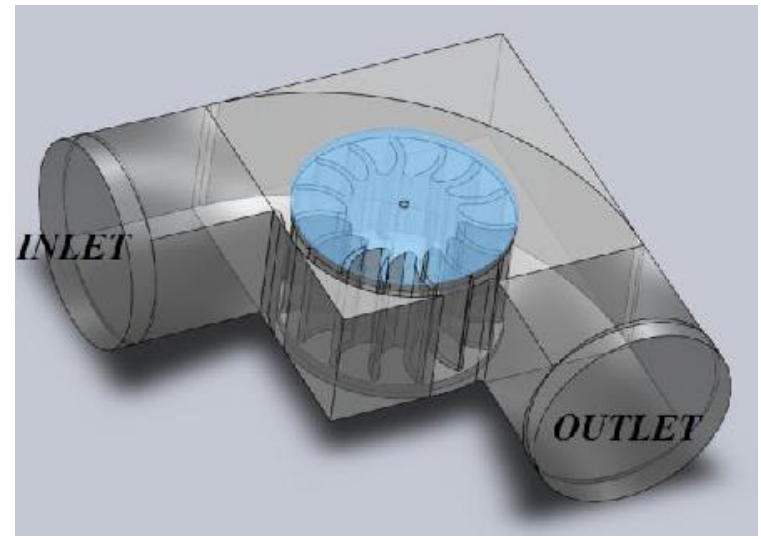

Figure 7. 3-D Assembly

\section{Performance Parameters of Turbine}

The design parameters are coefficient of head, coefficient of flow and coefficient of power. The performance features of the various turbine parameters are compared with each other. Both functional and non-dimensional features are traced using Origin Pro.
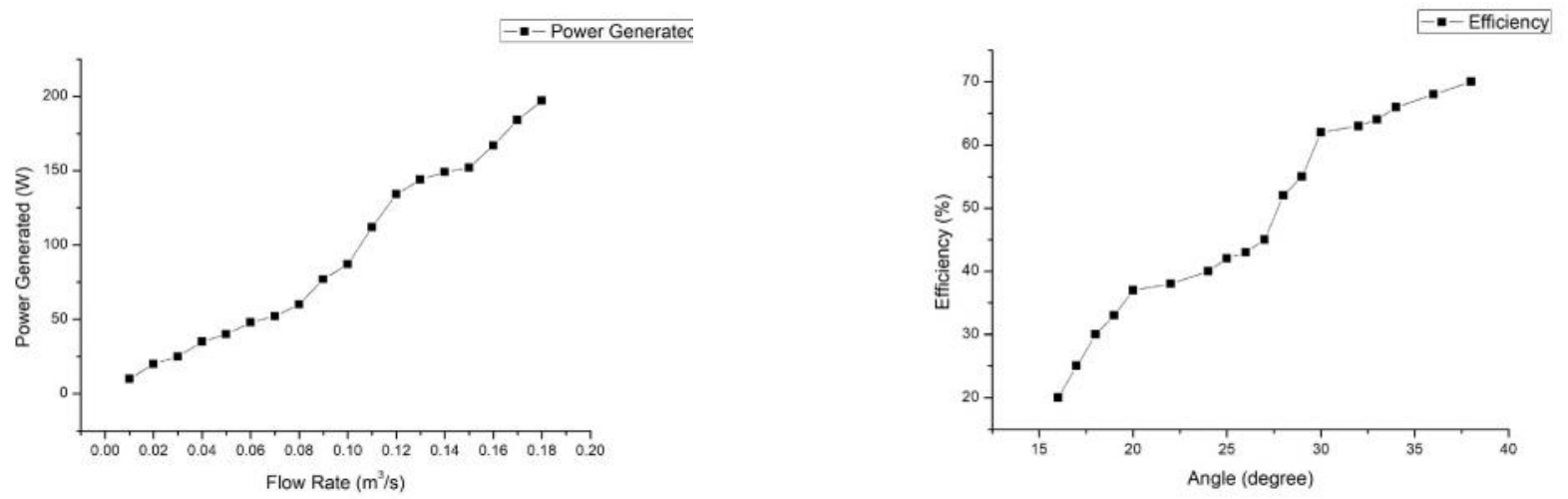
Figure 8. Performance curve between shaft power and flow rate

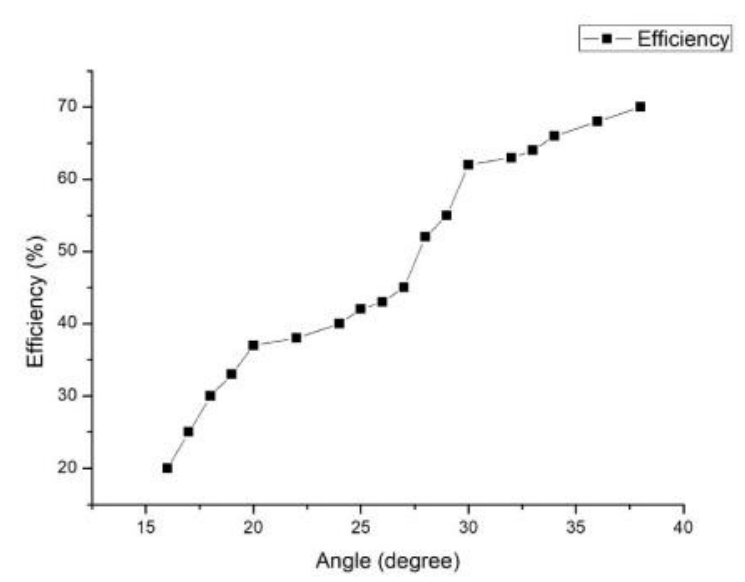

Figure 10. Performance curve between Guide Vane and Efficiency
Figure 9. Performance curve between shaft power and effective head

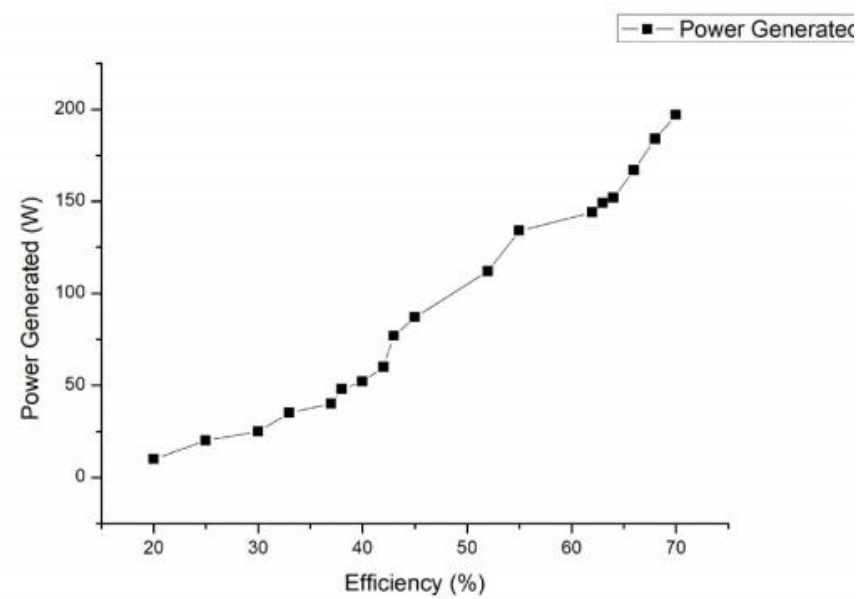

Figure 11. Performance curve between Power and Efficiency

Figure 8 illustrates a change of the shaft power with change in flow rate. As per the Figure 9 efficient shaft power and efficient heads are in direct relation, as the shaft power increases, the efficient head increases. Also, the performance curve between guide angle and efficiency is in direct relation, so increase in guide vane angle generates more power and provide facilitation of the sewage flow. The curve of efficiency and power is shown in Figure 10.

\section{Conclusions}

The flow duration at the location of the LMQ road sewage line was inspected and the potential of the sewage for electricity production was estimated to search for potential micro cross flow turbine installation in the sewage. The study shows that the attachment point has enough hydraulic potential to be used during the whole year. An installation of a crossflow turbine on the attachment point was examined considering the effectiveness and waste-matter passage through micro cross flow turbine. The investigation shows that the fiber attachment to the micro cross flow turbine is suppressed by a runner with rounded blades and guide vane with tapered blades, thus increasing Turbine Efficiency. It was therefore observed that micro crossflow turbine could be used to generate enough electricity from sewage flow in pipes.

\section{Nomenclature}

$\begin{array}{llll}\mathrm{a} & \text { Radial Rim Width } & \alpha & \text { Angle of Attack } \\ \beta & \text { Blade Angle } & \mathrm{CFD} & \text { Computational Fluid Dynamics } \\ \mathrm{d}_{\mathrm{s}} & \text { Shaft Diameter } & \mathrm{D}_{1} & \text { Outer Diameter } \\ \rho & \text { Density of Water } & \mathrm{o} & \text { Overall Efficiency } \\ \Psi & \text { Empirical Coefficient } & \mathrm{g} & \text { Gravity } \\ \mathrm{H} & \text { Head } & \mathrm{K}_{\mathrm{c}} & \text { Coefficient of Water Velocity } \\ \mathrm{K}_{\mathrm{u}} & \text { Coefficient of Velocity } & \mathrm{L} & \text { Length of Runner } \\ \mathrm{MCFT} & \text { Micro Cross Flow Turbine } & \mathrm{N} & \text { Number of Blades } \\ \mathrm{N} & \text { Turbine Speed } & \mathrm{N}_{\mathrm{s}} & \text { Specific Speed } \\ \mathrm{P} & \text { Power Generated } & \mathrm{Q}_{1} & \text { High flow rate } \\ \mathrm{Q}_{2} & \text { Ordinary flow rate } & \mathrm{Q}_{3} & \text { Low flow rate } \\ \mathrm{Q}_{4} & \text { Drought flow rate } & \mathrm{Q} & \text { Average flow rate } \\ \mathrm{r}_{1} & \text { Outer Circle Radius } & \mathrm{r}_{2} & \text { Inner Circle Radius } \\ \mathrm{r}_{\mathrm{c}} & \text { Blade Curvature Radius } & \mathrm{R}_{\mathrm{o}} & \text { Radius of Circle Pitch of Blade } \\ \mathrm{t} & \text { Blade Spacing } & \mathrm{u} & \text { Water Velocity }\end{array}$

WASA Water and Sanitation Authority 


\section{Acknowledgement}

The author especially thanks to Engr. Shoukat Ali Mugheri, Assistant Professor, Department of Mechanical Engineering, Pakistan Institute of Engineering and Technology, Multan for his kind supervision, suggestion and valuable guidance of this paper. The authors wish to thank the Water and Sanitation Authority for their support and providing sewerage flow data. In addition, the author wishes to thank our parents for their encouragement and help in making this study successful.

\section{References}

Acharya, N., Kim, C., Thapa, B., and Lee, Y., 2015, Numerical analysis and performance enhancement of a cross-flow hydro turbine, Renewable Energy, Vol. 80, pp. 819-826, https://doi.org/10.1016/j.renene.2015.01.064.

Adhikari, R., and Wood, D., 2018, The design of high efficiency crossflow hydro turbines: A review and extension, Energies, Vol. 11, No. 2, pp. 1-18, https://doi.org/10.3390/en11020267.

Alexander, K. V, Giddens, E. P., and Fuller, A. M. 2009, Axial-flow turbines for low head microhydro systems, Renewable Energy, Vol. 34, No. 1, pp. 35-47, https://doi.org/10.1016/j.renene.2008.03.017.

Aplicada, N., 2004,Turbinas Pelton. Ph.D. Thesis, Universidad Nacional Del Comahue, Neuquén Capital, Patagonia Argentina Area, A., Energy, D., Length, F., and Mass, M. 2013. Conversion Factors from BG to SI Units.

Cabra, H., 2014, Design, simulation, prototype, and testing of a notched blade energy generation system, Graduate Theses and Dissertations, https://scholarcommons.usf.edu/etd/4992

Chen Z., Choi Y.D., 2013, Performance and internal flow characteristics of a cross-flow turbine by guide vane angle, IOP Conference Series: Materials Science and Engineering, Vol. 52, ID052031, pp. 1-7, doi:10.1088/1757-899X/52/5/052031

Chichkhede, S., Verma, V., and Kumar, V., 2016, A simulation based study of flow velocities across cross flow turbine at different nozzle openings, Procedia Technology, Vol. 25, pp. 974-981, https://doi.org/10.1016/j.protcy.2016.08.190

Dakers, A. J., and Martin, G. 1982. Development of a simple cross-flow water turbine for rural use [New Zealand]. Agricultural Engineering Conference 1982 : resources--efficient use and conservation, Armidale, NSW, 22-24 August 1982, preprints of papers / National Commit. Agric. Engineering of Institution of Engineers, Australia. Barton, A.C.T. : The Institution, 1982.

Date, A., and Akbarzadeh, A. 2009, Design and cost analysis of low head simple reaction hydro turbine for remote area power supply, Renewable Energy, Vol. 34, No. 2, pp. 409-415, https://doi.org/10.1016/j.renene.2008.05.012

Desai, V. R. 2017. /, 9402.

Desai V.R., 1993, A parametric study of the cross-flow turbine performance, Ph.D. Thesis, Department of Civil Engineering, Graduate School of Clemson University, USA.

Diego, J., and Restrepo, P. 2012. Study of the operation and proposal for redesign of a prototype of a Michell-Banki picoturbine, EAFIT University, http://hdl.handle.net/10784/4230

Díez, P. F. 2009. Turbinas Hidráulicas, pp. 1-26.

Durali, M., 1979, Design of Small Water Turbines for Farms and Small Communities. Ph.D. Thesis, Massachusetts Institute of Technology, Cambridge, MA, USA.

Durgin W., Fay W., 1984, Some fluid flow characteristics of a cross-flow type hydraulic turbine. In SmallHydro Power Fluid Machinery; ASME: New York, NY, USA, pp. 77-83.

Elbatran, A. H., Yaakob, O. B., Ahmed, Y. M., \& Shabara, H. M. 2015. Operation, performance and economic analysis of low head micro-hydropower turbines for rural and remote areas: A review, Renewable and Sustainable Energy Reviews, Vol. 43, pp. 40-50, https://doi.org/10.1016/j.rser.2014.11.045.

Falconi C., Mantini G., D’Amico A. \& Wang Z.L. 2009, Studying piezoelectric nanowires and nanowalls for energy harvesting, Sensors and Actuators B: Chemical, Vol. 139, No. 2, pp. 511-519, https://doi.org/10.1016/j.snb.2009.02.071.

Fiuzat A., Akerkar B., 1989, The use of interior guide tube in cross flow turbines. In Waterpower'89, Proceedings of the International Conference on Hydropower, Niagara Falls, NY, USA, 23-25 August1989; American Society of Civil Engineers: New York, NY, USA, pp. 1111-1119.

Ghalichechian N., Modafe A., Beyaz M.I. \& Ghodssi R. 2008, Design, fabrication, and characterization of a rotary micromotor supported on microball bearings, Journal of Microelectromechanical Systems, Vol. 17, No. 3, pp. 632-642, doi: 10.1109/JMEMS.2008.916346

Hothersall R., 1985, A review of crossflow turbine, Proceedings of the International Conference on Hydropower, ASCE, Las Vegas, NV, USA, pp. 25-33

Ikeda, T., Iio, S., and Tatsuno, K. 2010. Performance of nano-hydraulic turbine utilizing waterfalls, Renewable Energy, Vol. 35, No. 1, pp. 293-300, https://doi.org/10.1016/j.renene.2009.07.004.

Japan Sewage Works Association. 2014.

Jeon, B. S., Park K.J., Song S.J., Joo Y.C., and Min K.D., 2005, Design, fabrication, and testing of a MEMS microturbine, Journal of Mechanical Science and Technology, Vol. 19, pp. 682-691, https://doi.org/10.1007/BF02916190

Johnson W., White E.R., White F., 1982, Design and testing of an inexpensive crossflow turbine. In Small Hydropower Fluid Machinery; ASME: New York, NY, USA. 
Khan M.A. and Badshah S., 2014, Design and analysis of cross flow turbine for micro hydro power application using sewerage water, Research Journal of Applied Sciences, Engineering and Technology, Vol. 8, No. 7, pp. 821-828, doi: 10.19026/rjaset.8.1040.

Khosrowpanah S., Fiuzat A.A., Albertson M.L., 1988, Experimental study of crossflow turbine. Journal of Hydraulic Engineering, Vol. 114, No. 3, pp 299-314, doi:10.1061/(ASCE)0733-9429(1988)114:3(299).

Macmore, C.; Merryfield, F., 1949, The Banki WaterTurbine; Engineering Experiment Station: College Station, TX, USA

Montanari, R. 2003. Criteria for the economic planning of a low power hydroelectric plant, Renewable Energy, Vol. 28, No. 13, pp. 2129-2145, https://doi.org/10.1016/S0960-1481(03)00063-6.

Murtaza, G., Ghafoor, A., Qadir, M., Owens, G., Aziz, M. A., and Zia, M. H. 2010. Disposal and use of sewage on agricultural lands in Pakistan: A review, Pedosphere: An International Journal, Vol. 20, pp. 23-34

Nakase, Y.; Fukutomi, J.; Watanabe, T.; Suetsugu, T.; Kubota, T.; Kushimoto, S. 2014. A study of cross-flow turbine (effects of nozzle shape on its performance). Phoenix, AZ, USA: ASME.

Nasir, A., \& Akbar, F. N. 2015. Impact of Sewage and Industrial Effluents on Water Quality in Faisalabad , Pakistan, 9: 53-58.

Nishi Y., Inagaki T., Li Y., Omiya R. and Fukutomi J. 2014, Study on an undershot cross-flow water turbine, Journal of Thermal Science, Vol. 23, pp. 239-245

Nuet, N. S., Soe, M. M., and Thu, A. M. 2016, Experimental investigation of cross-flow turbine, pp. 83-88.

Ott, R.F.; Chappell, J.R., 1989, Design and efficiency testing of a cross-flow turbine. In Waterpower'89, Proceedings of the International Conference on Hydropower, Niagara Falls, NY, USA, 23-25 August 1989; ASCE: New York, NY, USA, pp. 1534-1543.

Pacific, A., Asia, S., \& Frei, C. 2009. Survey of Energy Resources Interim Update 2009 Officers of the World Energy Council.

Patel, M., \& Oza, N. 2016. Design and analysis of high efficiency cross- flow turbine for hydro-power plant, pp. 187-193.

Paul, D. 1997. Handbook of Energy Engineering

Pereira, N. H. C. 2009. A study on the efficiency of a cross-flow turbine based on experimental measurements, pp. 63-72.

Prajapati, P. V. M., Patel, P. R. H., \& Thakkar, P. K. H. 2015. Design, Modeling \& Analysis of Pelton Wheel Turbine Blade, Vol. 3, pp. 159-163.

Rantererung, C. L., Tandiseno, T., \& Mallisa, M. 2018. Development of cross flow turbine with multi nozzle, Vol. 13, pp. 249254

Reihani, A., Ojaghi, A., Derakhshan, S., \& Beigzadeh, B. 2014. Shaft fatigue life and efficiency improvement of a micro cross flow turbine, Vol. 2, pp. 1-14.

Ricardo, M., \& Ricardo, M. 2007. Universidade Federal De Itajubá Estudo De Grupos Moto-Bomba Operando Como Grupos Geradores Em Microcentrais Hidrelétricas Itajubá Estudo De Grupos Moto-Bomba Operando Itajubá.

Runner, C. 2015. Investigation of Blade Angle of an Open, Vol. 32, pp. 65-72.

Sammartano, V., Aricò, C., Carravetta, A., \& Fecarotta, O. 2013. Banki-Michell Optimal Design by Computational Fluid Dynamics Testing and Hydrodynamic Analysis, pp. 2362-2385.

San, M., \& Nyi, N. 2018. Design of cross flow turbine and analysis of runner's dimensions on various head and flow rate, Vol. 8, pp. 586-593.

Scoe, M. E., 2017. Footstep Power Generation, Vol. 2, pp. 8-13.

Sinagra, M., Sammartano, V., Aricò, C., Collura, A., \& Tucciarelli, T., 2014, Cross-flow turbine design for variable operating conditions, Procedia Engineering, Vol. 70, pp. 1539-1548.

Singh, P., and Nestmann, F. 2011. Experimental investigation of the influence of blade height and blade number on the performance of low head axial flow turbines, Renewable Energy, Vol. 36, pp. 272-281.

Stark, B. H., Andò, E., and Hartley, G. 2011. Modelling and performance of a small siphonic hydropower system, Renewable Energy, Vol. 36, pp. 2451-2464

Supervisor, T. 1976. Jul 91976.

Tiwari, M., and Shrestha, R. 2017. Effect of variation of design parameters on cross flow turbine efficiency using ANSYS, Vol. 13, pp. 1-9.

Totapally H.G., Aziz, N.M., 1994, Refinement of cross-flow turbine design parameters, Journal of Energy Engineering, Vol. 120, pp 133-147, https://doi.org/10.1061/(ASCE)0733-9402(1994)120:3(133).

Turbine, B. W. 1949. Banki Water Turbine.

Uchiyama, T., Honda, S., and Degawa, T., 2018, Development of a propeller-type hollow micro-hydraulic turbine with excellent performance in passing foreign matter, Renewable Energy, Vol. 126, pp. 545-551, https://doi.org/10.1016/j.renene.2018.03.083.

Uchiyama, T., Honda, S., Okayama, T., and Degawa, T. 2016, A feasibility study of power generation from sewage using a hollowed pico-hydraulic turbine, Engineering, Vol. 2, pp. 510-517, https://doi.org/10.1016/J.ENG.2016.04.007.

Uchiyama, Y., and Morita, R. 2017, Expansion of multi-purpose steam facility and application to acoustic resonance in a closed side branch investigating effects of static pressure under wet steam flow, Proceedings of the ASME 2017 Pressure Vessels and Piping Conference. Volume 4: Fluid-Structure Interaction. Waikoloa, Hawaii, USA. V004T04A028. ASME.

Umer, M., Badshah, S., Iman, M., \& Rafai, A. (n.d.). Design and Analysis of cross flow impulse turbine for water stream near Trapi village KPK Pakistan. 
Varga, J., 1959, Tests with the Banki water turbine, Acta Technica Academiae Scientiarum Hungaricae, Vol. 26, pp 79-102

Vincenzo S., Arico C., Carravetta A. and Fecarotta O., 2012, Banki-Michell optimal design by computational fluid dynamics testing and hydrodynamic analysis, Energies, Vol. 6, pp. 2362-2385, https://doi.org/10.3390/en6052362.

Mtalo M., Wakati R., Towo A., Makhanu S.K., Munyaneza O., Abate B., 2010, Design and fabrication of cross flow turbine, Nile Basin Capacity Building Network, Project Report by UNESCO-IHE Institute for Water Education, Delft, The Netherlands (UNESCO-IHE), pp. 1-39

Williamson, S. J., Stark, B. H., and Booker, J. D. 2014, Low head pico hydro turbine selection using a multi-criteria analysis, Renewable Energy, Vol. 61, pp. 43-50, https://doi.org/10.1016/j.renene.2012.06.020.

Yang R., Qin Y., Li C., Zhu G., Wang Z.L., 2009, Converting biomechanical energy into electricity by a muscle-movement-driven nanogenerator, Nano Letters, Vol. 9, No. 3, pp. 1201-1205, https://doi.org/10.1021/nl803904b.

\section{Bibliographical notes}

Muhammad Hamza Tahir was born in Multan, Punjab, Pakistan in 1995. He obtained his Bachelor degree in mechanical engineering(Gold Medalist) in 2018 from Pakistan Institute of Engineering and Technology, Multan. Currently, he is working as research associate in the department of mechanical engineering at Pakistan Institute of Engineering and Technology, Multan. His research interests include machine design, renewable energy resources and fracture mechanics.

Shoukat Ali Mugheri was born in Larkana, Sindh, Pakistan. He obtained his bachelor's degree in mechanical engineering from QUEST, Nawab shah. He completed his postgraduation in design engineering from NED university, Karachi. Currently he is working as assistant professor at Pakistan Institute of Engineering and Technology, Multan. His research interest includes design and renewable energy.

Mughees Shahid was born in Multan, Punjab, Pakistan. He obtained his bachelor's degree in mechanical engineering from BZU, Multan. He completed his postgraduation in design and manufacturing engineering from Comsats University, Sahiwal. Currently he is working as Lecturer at Pakistan Institute of Engineering and Technology, Multan. His research interest include design, energy efficient systems and computational fluid dynamics.

Salman Ahmad was born in Multan, Punjab, Pakistan. He obtained his Bachelor degree in mechanical engineering in 2018 from Pakistan Institute of Engineering and Technology, Multan. Currently, he is working as lab engineer in the department of mechanical engineering at Pakistan Institute of Engineering and Technology, Multan. His research interests include renewable energy resources.

Nouman Zaffar was born in Multan, Punjab, Pakistan. He obtained his Bachelor degree in mechanical engineering in 2018 from Pakistan Institute of Engineering and Technology, Multan. Currently, he is working as workshop supervisor in the Honda Breeze, Multan. His research interests include renewable energy resources and Fracture Analysis.

Muhammad Asad Saeed was born in Multan, Punjab, Pakistan. He obtained his Bachelor degree in mechanical engineering in 2018 from Pakistan Institute of Engineering and Technology, Multan. Currently, he is working as workshop supervisor in the Honda Atlas, Multan. His research interests include renewable energy resources and Fracture Analysis.

Muhammad Arsalan Malik was born in Multan, Punjab, Pakistan. He obtained his Bachelor degree in mechanical engineering in 2018 from Pakistan Institute of Engineering and Technology, Multan. Currently, he is working as production manager in the Hafiz Foundry, Multan. His research interests include renewable energy resources.

Received September 2019

Accepted October 2019

Final acceptance in revised form April 2020 